\title{
落石覆工の設計の現状と合理的設計へのアプローチ
}

\section{A SURVEY OF DESIGN OF ROCK SHEDS AND AN APPROACH TO IMPROVED DESIGN}

\author{
吉田 博*. 栘谷浩**. 右城 猛***. 柴田健次****
} By Hiroshi YOSHIDA, Hiroshi MASUYA, Takeshi USHIRO and Kenji SHIBATA

\begin{abstract}
A survey of the design method of preventive structures against rock falls and an improved design procedure are presented.

At first, a current investigative procedure of slopes before the design of preventive structures is outlined and a present design method is generally remarks. Secondly, a motion of falling rocks and an estimation of falling speed and location of rocks are described.

Thirdly, many formula estimating impact design load derived from the elastic contact theory, the elastic or visco-elastic and plastic theory and experimental results are discussed.
\end{abstract}

Finally, a rational design procedure is proposed.

Keywords : rock shed, falling rock, design method, slope

\section{1. まえがき}

道路交通の安全確保を図るため, 道路整備の一環とし て道路防災対策事業が進められており，落石対策におい ても着実にその成果をあげてきている.

落石防護工の設置にあたっては，斜面調査による岩石 の特定, 落下経路, 跳踓量, 落下位置および速度などの 推定, 落石による衝撃力およびクッション材による緩衝 効果の検討, 防護工の選定, 防護工の動的挙動の検討な どを必要とする。しかし, 比較的地形, 地質条件に恵ま

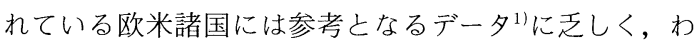
が国においても断片的にこれらの研究が進められていた が，1978 年には日本鉄道施設協会より，1983 年には日 本道路協会よりこれらの研究を集大成した落石対策の手

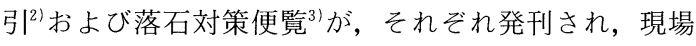
技術者および設計者に，効果的に利用されてきた.

しかし, 発刊以来すでに 7〜11 年を経過し, その内容

* 正会員 工博 元・金沢大学教授 (\%932-01 小矢部市水島 561)

** 正会員 工博 金沢大学助手 工学部土木建設工学科 ( T920 金沢市小立野 2-40-20)

*** 正会員 (株) 第一コンサルタンツ常務取締役 ( ₹780 高知市高須新町 3-1-5)

**** 正会員 日本工営 (株) 関東支店設計課長 （预330 大宮市宮町 3-13-2)
が実状に必ずしもマッチしない面も見受けられ, 内容の 見直しの要望もでてきている. 特に, 1989 年 6 月に発 生した福井県越前海岸での落石覆工(以後, ロックシェッ ドという)の崩壊事故 ${ }^{4), 5)}$ は, 社会的に大きい関心を呼び, 改めて落石防護に対する考え方を明確にする必要性に迫 られている.

本報告はこのような観点から，ロックシェッドの設計 の現状とその問題点について述べ，ロックシェッドの設 計に対する基本的な考え方およびより合理的な設計手法 について検討する.

\section{2. 落石の調査および覆工設計の現状}

現在, ロックシェッドの設計は, 一般に図一1に示す 手順で行われている. 以下, このフローチャートに従い, 各項目ごとにその内容を検討する.

\section{（1）調査}

落石対策の調査にあたっては, 落石が予想される区域, 落石の発生形態, 規模, 運動形態, 地形, 地質条件等を 的確に判断しなければならない.

落石危険筒所では, 落石が繰り返し発生していること が多い㬏ので, 落石の履歴調査を実施するとともに, 現 地踏査により, 落石予備物質の有無を確認する必要があ る. 


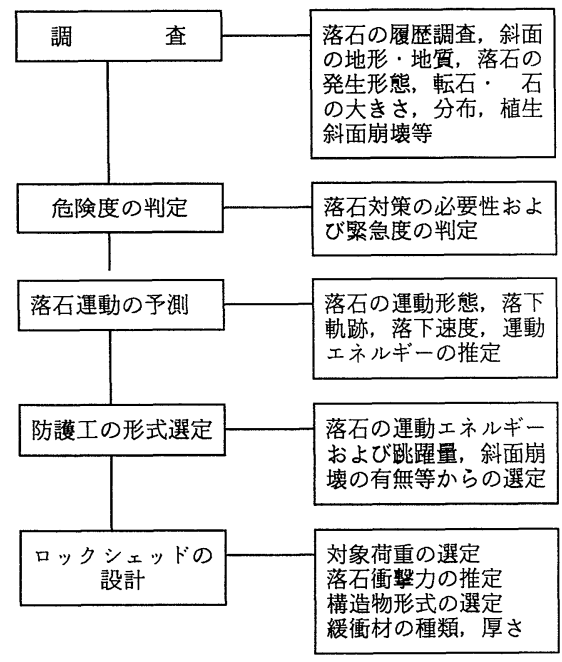

図一1ロックシェッドの設計の手順

落石のエネルギーは, 落石や斜面の特性により著しく 異なるため, 落石の発生地点, 重量, 形状, 斜面の勾配, 凹凸，樹木の繁茂状況，浮石，転石の分布状況等を調査 する必要がある．また，必要に応じてボーリング等によ り危険箇所の地盤性状を把握することもある ${ }^{3,6) ~ 11) . ~}$

\section{（2）危険度の判定}

落石の危険度とは, 対象物件への影響を災害の発生頻 度と規模から総合的に判定した結果であり，判定方法お よび判定事例は，落石対策便覧 ${ }^{3)}$ の資料編に指針案が記 載されている。しかし，調査がかなり大がかりであるこ と，オーソライズされた方法がないこと，また，○×の 数2),11)や点数による評価 ${ }^{6), 13)}$ により, 落石の相対的危険 度は評価できても絶対的危険度を判定することは困難で ある。このような採点法を補完する手法として，土質力 学的考察に基づいた検討もみられる ${ }^{14)}$-16) が, 実用化に は詰めるべき問題が残されている.

このような実状から，一般的に危険度の判定は現場踏 查時に行い, 地形的要素として, 斜面が高かったり, 勾 配が急峻であったり，オーバーハングしているなどの場 合, 危険度が高いと判断している. 落石の形態としては, 玉石や岩塊の抜け落ち型の場合は, 地山全体の緩みや固 結度, 剝離型の場合は, 岩盤の割れ目の発達の程度や方 向を観察して危険度が判定される゙!。

\section{（3）落石防護工の選定}

落石対策工は，落石予備物質を取り除いたり，斜面に 固定する落石予防工と, 斜面から転落あるいは落下して くる落石を受け止める落石防護工に分類される.

落石防護工には, 落石防止網, 落石防止柵, 落石防止 壁等の比較的落石エネルギーの小さい場合に対する構造 物と, 大きなエネルギーに対処できるロックシェッドに 分類される ${ }^{3), 17)}$.
落石防護工の選定にあたっては, 落石エネルギー, 地 形条件, 地質条件, 道路条件, 施工条件等を考慮して選 定される。ロックシェッドの場合は, 他の落石防護構造 物と比へ，構造規模が大きく, 高価であり, また, 永久 構造物として使用されることから, より信頼性および耐 久性に優れた設計が求められている.

ロックシェッドには, PC (プレストレストコンクリー ト）製， RC (鉄筋コンクリート) 製, 鋼製のものがあ り,これらは主として, 落石規模, 施工条件などにより 使い分けられている3.

\section{（4）落石径および落石重量の推定}

設計の対象とする落石の大きさは, 過去の資料, 現地 踏查などに基づき決定される ${ }^{17)}$.一般には耐用期間中に 起こると考えられる落石を対象としているが，落下の可 能性についての判定は, 設計者の経験的判断に委福られ ていることが多い.

\section{（5）落石の運動と落下位置・落下速度の推定}

落石の発生位置は, 現地踏査により設計の対象となる 落石の最高地点を推定して決めている. 特に落下高が高 く明瞭な遷急点がある場合には, その位置を落下位置と している.

落石の運動形態, 落下位置および落下速度の推定法に ついては，章を改めて検討する.

\section{（6）落石による衝撃力およびその分布}

ロックシェッドの設計のための落石による衝撃力の算 定法およびその分布については，章を改めて検討する.

\section{（７）ロックシェッドの設計}

落石防護工の設計は, 落石防止網, 落石防止柵, 落石 防止擁壁などのように, 落石の運動エネルギーと構造物 の塑性変形による吸収エネルギーに基づいた設計法と, ロックシェッドのように落石の衝撃荷重を静的荷重に置 き換えて, 弾性理論に基づく許容応力度法による設計法 に分けられる ${ }^{31}$. 前者は構造形式が比較的単純で, 変形 容量の計算が簡単であるが, 後者にあっては, 構造物の 規模および重要度が大であり,したがって変形の許容值 の決定が困難であることなどによっている31.

ロックシェッドの設計荷重として, 落石荷重以外に積 雪荷重, 雪崩荷重, 崩土荷重, 堆積土荷重等についても 必要に応じて考慮される.

前述のとおり, 現在, ロックシェッドは落石対策便覧 を参考にして設計されている. 落石対策便覧では, ロッ クシェッドの設計は許容応力度法によるのが適当である とし, 許容応力度については, 基本的には道路橋の場合 に準じるものとしている．すなわち，道路橋示方書 ${ }^{18}$ に 規定されている許容応力度を使用し，規定されていない 事項については，コンクリート標準示方書 ${ }^{191,20)}$ な゙゙が参 考になるとしている，さらに，荷重の組合せに対する許 
表一1 既往の現場落石実験の概要

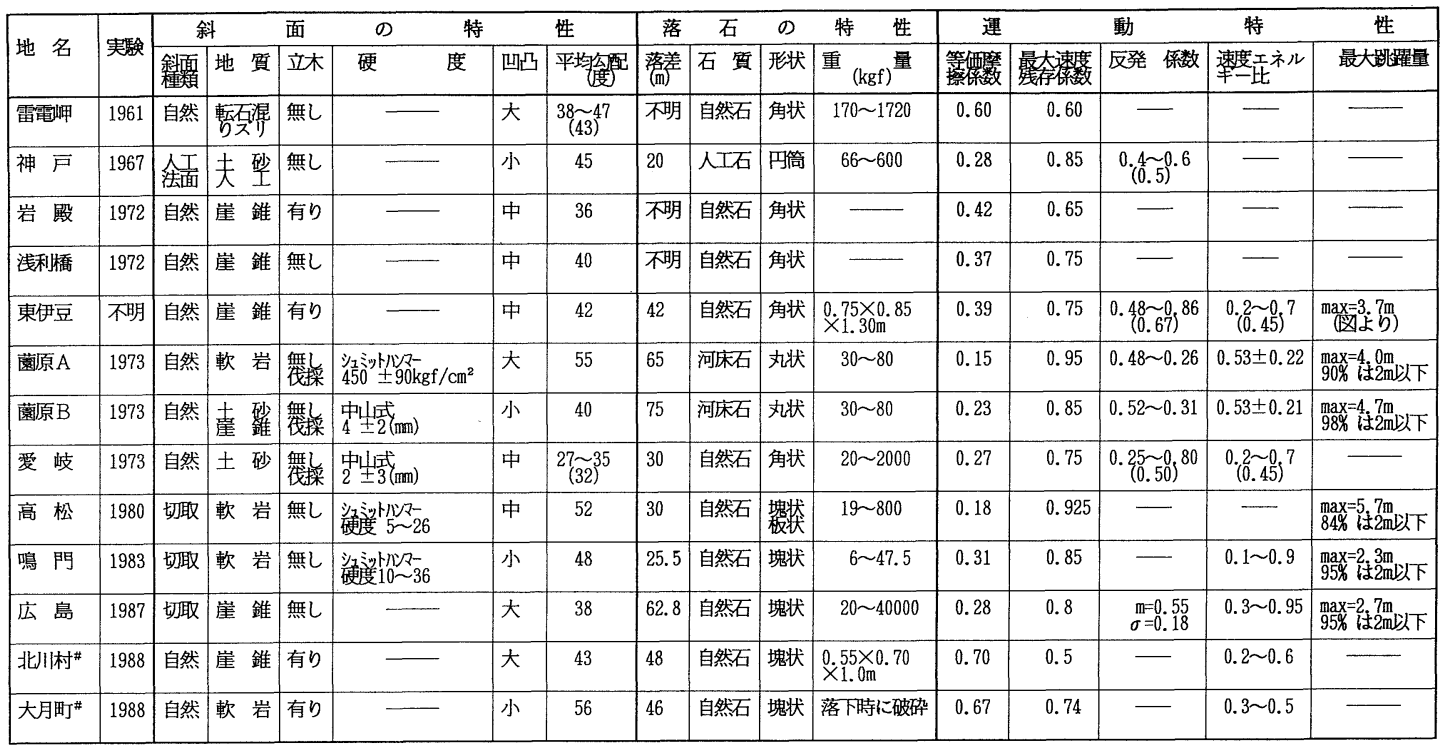

\#痕跡調查による.

容応力度の割增率は, 道路橋示方書における地震時の規 定を準用している.

道路橋における荷重, 許容応力, 荷重の組合せに対す る許容応力の割増なぼについては, 数多くの研究が成さ れ，その成果が反映されているが，ロックシェッドにお けるそれらの研究はきわめて少なく, 落石時の許容応力 度の割増率を道路橋示方書における地震時の規定に準じ て決定しているなよ゙，道路橋に準じた取扱いもやむを得 ない面もあるが，基本的にはロックシェッドは橋梁とは 異なった設計思想で設計されるべき性格の構造物である と考えられる.

\section{3. 落石の運動形態}

\section{（1）運動形態の分類}

落石防護工を計画・設計するうえで，斜面を落下する 落石の跳躍量・平面的落下経路・防護工への衝突速度を 予測することはきわめて重要といえる。これらの予測を 誤ると, 落石の防護工上の飛び越え, 防護工設置外への 落下，あるいは防護工の破壊等によって重大な事故を招 くおそれがある。

落石の運動形態は，すべり・転がり・跳躍・衝突運動 に分類される．斜面上で発生した落石はこのような運動 形態を繰り返しつつ, 運動エネルギーを増加しながら落 下する.ところが,これらの運動は, 斜面の形状・勾配・ 凹凸・地質 - 植生状況, 落石の形状 - 寸法・岩質等の影 響を顕著に受けるため, 運動力学的理論解析だけでもつ て予測することはきわめて困難である211.

こうしたことから,これまで, 現場落石実験 ${ }^{121,221 ~ 271, ~}$
模型実験28), 落石斜面での痕跡調査に基づいた研究 ${ }^{29), 30)}$ によって運動形態を解明する試みがなされてきた。

\section{（2）落石の運動特性}

落石の運動形態の解明を目的とした現場落石実験とし ては, 表一1に示すものがあり，これらの実験結果から 以下のような落石の運動特性が明らかにされている.

\section{a) 落石の速度}

斜面上を落下する落石の速度 $(V)$ は，同一高さからの 自由落下速度 $\left(V_{0}\right)$ に比べて小さい.

速度残存係数 $\alpha\left(=V / V_{0}\right)$ は, 崖錐斜面の場合 $\alpha=$ $0.6 \sim 0.85^{24), 25), 27), 29)}$ (それぞれの実験結果を包含する最 大值), 岩盤斜面の場合 $\alpha=0.85 \sim 0.96^{23), 24), 31)}$ である. ただし，立木があるとこれより小さな值となる ${ }^{30}$.

落石の運動をすべり運動と仮定したとき, 落石の速度 之同一の速度を与える動摩擦係数を等価摩擦係数 $\mu$ $\left(=\tan \theta\left(1-\alpha^{2}\right), \theta\right.$ : 斜面勾配 $)$ 之定義すれば，等価摩

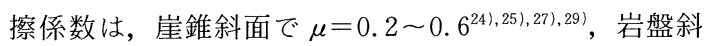
面で $\mu=0.15 \sim 0.3^{231,24), 31)}$ となる.ただし，立木がある とこれよりも大きくなる301.

斜面上を落下する落石の速度は, 落差が $40 \sim 50 \mathrm{~m}$ に なると一定値に収束する傾向にある ${ }^{24,277}$.

b) 反発係数, 落石の運動エネルギー

落石が斜面に衝突する際の反発係数は，斜面の凹凸や 落石の形状の影響が顕著に現われ, 実験值のばらつきが 大きいが，その平均値は崖錐斜面・岩盤斜面にかかわら ず 0.5 程度である ${ }^{24) ~ 27) . ~}$

速度エネルギー比 (斜面に衝突する直前と直後の運動 エネルギーの比）も，反発係数とほぼ同様の傾向がみら 
れ, 平均值は 0.5 程度である ${ }^{24), 25), 27) .}$

落石の運動エネルギ一は，線速度エネルギーと回転エ ネルギーの和で表わされ, 回転エネルギーは線速度エネ ルギーの約 1/10である ${ }^{31,12), 31) .}$

c) 落石の跳躍量

落石の軌跡の包絡線は, ある落差まで 2 次曲線で増大 するが，それを越えると一定值に収束する傾向がみられ る $^{24), 27)}$.

最大跳躍量は，ほとんどが $2 \mathrm{~m}$ 以下である ${ }^{23), 24), 27), 31)}$ が，斜面の凹凸が大きい場合には 5 〜 $\mathrm{m}$ に達すること もある12).

d）落石の平面的落下経路

落石は, 地形のコンターラインの法線に対してある分 散角をもって落下する，分散角は，落石の規模が大きい ほど小さ(27),31)

\section{（3）落石の運動軌跡, 落下速度の予測}

落石の運動軌跡あるいは落下速度を予測する方法は, 経験則による方法と力学的数值解析による方法とに大別 される。

落石対策便覧 ${ }^{3)}$ では, 落石の最大跳躍量の標準值とし て $2.0 \mathrm{~m}$ を, また, 落下速度 $(V)$ の推定式として等価摩 擦係数 $(\mu)$ を用いた式, $V=\sqrt{2 g H[1-(\mu / \tan \theta)]}$ を採 用している.ここに， $g$ は重力の加速度， $H$ は落下高さ, $\theta$ は斜面の勾配である.これは，前者の予測法に基づい たものであり，過去の実験データのほぼ最大值（または 最小值）が与えられているため予測を大きく誤るおそれ は少ない。しかしながら，この方法では，斜面の性状を 定量的に評価した予測が行えないという久点がある。た とえば，斜面勾配が急変している場合，あるいは凹凹が 著しい場合に出現する跳躍量の大きい運動を予測するこ とができない。

また，式（1）は，ある落差になると落下速度が一定 值に収束するという実験結果を反映したものになってい ないため, 落差の大きい斜面に適用すると落下速度を過 大に評価するおそれがある.

数值解析法は, 落石を質点あるいは剛球にモデル化し, すべり，転がり，跳躍および衝突の運動形態に応じてそ れぞれ運動方程式 ${ }^{29), 32)}$ あるいは衝撃運動方程式 ${ }^{28)}$ を適用 し, 落石の運動軌跡, 落下速度などを計算で求めるもの

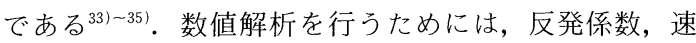
度エネルギ一比, 速度残存係数, 等価摩擦係数等の運動 特性值を推定する必要があるが，これまでの落石実験で も明らかなように実験データのばらつきが非常に大き く，信頼できる特性值を決定することは困難である.

こうしたことから, 右城ら ${ }^{21)}$ は落石実験データをもと に転がり運動から跳躍運動に移行する限界速度, 飛び出 し角度, 斜面への衝突前と衝突後の速度比等の正規分布
確率密度関数を求め, 確率密度関数の $95 \%$ 信頼区間で 乱数を発生させ, 確率論的に決定した值を用いて落石の 運動軌跡をシミュレーションする方法を提案するととも に，鳴門での落石実験 ${ }^{23)} よ り$ 得られた確率密度関数を別 の類似実験斜面に適用し，落石の最大跳躍量をかなりの 精度でシミュレートできることを確認している. また, 吉田ら ${ }^{35)}$, 古賀ら ${ }^{28)}$ は実験結果の再現性が高い運動基礎 方程式に関する研究を行い, 右城らと同様な手法で落石 の軌跡, 落下速度のシミュレーションを試みている.

他方，ヨーロッパにおいてもシミュレーションに関す る研究がなされている ${ }^{36 !}$. フランスでは, 地形データ, 斜面の地質, 落石の形状・大きさ, 落石の破砕, 斜面の 状態, 衝突時のエネルギー散逸などをパラメーターとし

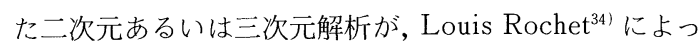
て試みられている。また，スイスには，落石が斜面へ衝 突した場合の運動エネルギーおよび速度の損失に関する Ritichie の実験的研究 ${ }^{37)}$ があるほか, スイス道路交通・ エネルギー経済省監修の設計指針，落石防護（第 2 版 $)^{11}$ のなかに, 落石の落下経路・エネルギーの計算方 法および数值計算例が示されているが, いずれも, 落石 防護工の設計にそのまま適用するには, 多くの問題を含 んでいる.

\section{（4） 今後の課題}

従来，落石の運動形態の予測は，経験的に行われてき た. しかし, 落石の運動は, 斜面の形状, 勾配, 凹凸, 地質, 植生, 落石の形状, 寸法, 岩質などの影響を顕著 に受けるため, 経験的判断のみで予測を行うのは危険で ある. 斜面勾配が急変している場合や凹凸が著しい場合 には, シミュレーション手法による確率論的数值解析も 併せて行う必要があろう。

シミュレーションの信頼性を高めるためには, 落石の 運動形態に適合した運動方程式の適用と落石および斜面 のモデル化が重要であるが，それ以上に，落石および斜 面の物理的, 幾何学的特性を斜面条件に応じて適切に評 価すること, すなわち, 物理的・幾何学的特性を表わす 確率密度関数のパラメーター (平均值, 標準偏差) の決 定が重要である.したがって, 今後においては, 条件の 異なる種々の斜面で落石実験を行いデータの蓄積を図っ ていく必要がある.また，立木があるような斜面では， 落石実験が困難であるため落石斜面での痕跡調査による デー夕収集も必要亡思われる.

\section{4. 落石による衝撃力}

落石がロックシェッド上に落下したときの衝撃力に関 する研究は, 昭和 40 年頃より始められ, いくつかの理 論式および実験式が提案されている.その主なものを以 下に示す。 


\section{（1）弾性接触理論による研究}

落石のサンドクッション上への落下衝突を, サンド クッションを半無限弾性体とし, その上に, 落石として 剛球が衝突するもの之仮定し，A.E.H. Love の 2 つの 弾性体が衝突するときの物体間の圧力に関する基礎方程 式より出発し, Hertz の接触論を用いて 2 物体間に働く 力を衝撃力として導いたもので，一般に振動便覧式とし てよばれている次式がある31,38).

$$
P=2.46 \lambda^{2 / 5} W^{2 / 3} H^{3 / 5}
$$

ここに, $W$ は落石の重量 $(\mathrm{tf}), H$ は落下高さ $(\mathrm{m}), \lambda$ はサンドクッションのラメ定数 $\left(\mathrm{tf} / \mathrm{m}^{2}\right)$ であり, 非常 に軟らかいもので $\lambda=100 \mathrm{tf} / \mathrm{m}^{2}$, 軟らかいもので $\lambda=$ $300 \sim 500 \mathrm{tf} / \mathrm{m}^{2}$, 固いもので $\lambda=1000 \mathrm{tf} / \mathrm{m}^{2}$ とされてい るが，土の力学的性質との具体的な関係は明らかにされ ておらず，落石対策便覧 ${ }^{3)}$ では $\lambda=100 \mathrm{tf} / \mathrm{m}^{2}$ が用いられ ており，これより得られる衝撃力は適当な厚さの緩衝材 では，実験結果の值を越えることがないとしている.

この理論式では, 実際はサンドクッション厚は有限で あること, サンドクッションの非弾性的特性, 落石形状 の影響等は考慮されていない。これらの問題点を検討す るために, 重鍾形状および有限砂層厚が落石の加速度に 与える影響に関する研究も成されている ${ }^{39) \sim 411}$ が, 設計 に取り入れられるには至っていない。

\section{（2）弾性理論および粘弾塑性理論による研究}

サンドクッションを弾性ば称と仮定し，落石がそのば ね上に衝突するものとして, 落石の位置エネルギーとば ねのひずみエネルギーが等しいという条件から，衝撃力 を導いたものに次式がある ${ }^{42}$.

$$
P=1.619 k^{1 / 4} W^{5 / 6} H^{1 / 2}
$$

ここに, $k$ はサンドクッションのばね定数 $\left(\mathrm{tf} / \mathrm{m}^{3}\right), W$ および $H$ は式 $(1)$ と同じである.

式（2）において, サンドクッションは実際には弾性 挙動を示さず，ばね定数としてどのような值を用いるか が問題となる.

式（1）の理論的な適用限界を明らかにし, Kelvin ・ Voigt モデルを用いてサンドクッションの非弾性性質を 考慮した衝撃力評価式に次式がある ${ }^{431}$.

$$
P=(W / g) \cdot v K^{1 / 2}\left(e^{\mu T_{a}} / 2\right)
$$

ここに,

$$
\begin{aligned}
& T_{a}=\frac{2}{\sqrt{\left(4 K-\mu^{2}\right)}} \cdot \tan ^{-1}\left\{\frac{K-\mu^{2}}{\mu\left(3 K-\mu^{2}\right)} \sqrt{4 K-\mu^{2}}\right\} \\
& \mu=10(\mathrm{~W} / \mathrm{g})^{-1 / 3}
\end{aligned}
$$

鉛直荷重に対して, $v=\sqrt{2 g H} \sin \theta, K=k_{v} g / W$, 水 平荷重に対しては, $v=\sqrt{2 g H} \cos \theta, K=k_{h} g / W$ で あり, $g$ は重力加速度 $\left(9.8 \mathrm{~m} / \mathrm{s}^{2}\right), \theta$ は落石の入射角, $k_{v}, k_{h}$ はそれぞれサンドクッションの鉛直と水平方向 のばね定数 $(\mathrm{tf} / \mathrm{m})$ であり，Wおよび $H$ は式 $(1)$ と
同じである.

さらに，ロックシェッドの剛性と質量を考慮したモデ ルについても研究が行われている33 46). これらのモデ ルによれば，衝撃力の定性的な評価を行うことができる が，落石の衝突に対し複雑な挙動を示すサンドクッショ ンを比較的簡易なモデルを用いて表現しているため, 具 体的な諸定数の決定方法やモデルの適用範囲が限られる などの問題点がある.

また，巨視的に連続体であるサンドクッションをある 大きさをもった土塊（要素）の集合体と仮定し, 各要素 間はばねとダッシュポットで連結されていると仮定し， それらの運動方程式を陽な方法で解く個別要素法を用 い, 落石のサンドクッション中への貫入状況, 底面での 土圧の発生状況などについて, 定量的な評価も行われて いるが47)，ばねおよびダッシュポットの定数の決定方法 になお問題が残されている ${ }^{48) ~ 50)}$.

\section{（3）破壊時のエネルギー吸収を考慮した研究}

落石対策便覧 ${ }^{31}$ には，落石防止網および柵においては， それらのエネルギー吸収能を考慮した設計がなされてい るが，ロック.シェッドの設計においては考虑されていな い.

園田ら ${ }^{51)}$ は, 落石が不確定性の強い現象であることよ り，まれに発生する非常に大きな落石を対象に，ロック シェッドの終局限界状態として曲げ破壊を仮定し, 破壊 時のメカニズム形成による変形に伴うエネルギー吸収を 考慮した落石による衝撃力の評価方法について検討を 行っている.

また，石川ら ${ }^{52}$ は，鋼製砂防ダムのエネルギ一吸収特 性の解明を目的として, 鋼部材の衝撃破壊について実験 的および解析的研究を行い, 衝突条件と破壊形式, 限界 吸収エネルギーなどの関係を明らかにしている．鋼製砂 防ダムの研究 531,54)では，岩石が直接鋼製砂防ダムに衝突 することを前提としており, 衝撃力の作用時間はロック シェッドの場合に比較してきわめて短いが，ロック シェッドの衝撃力の評価に示唆を与える研究である.

\section{（4）実験を中心とした研究}

鋼材俱楽部 ${ }^{577}$ では，実物大の鋼製ロックシェッドを用 いて, わが国で最初の落石実験を行っている．実験で得 られた最大加速度より, 衝撃力は次式で表わされる.

$$
P=\varkappa(W H / g) \text {. }
$$

ここに, $x$ は比例定数であり, 落下位置により異なる值 をとる.

この研究により, 落石の衝撃力の概要が初めて実験的 に明らかになった。

吉田ら ${ }^{58)}$ は， 3 種のサンドクッションを用いて, 実物 大の落石実験を行い, 加速度波形における作用時間 $T_{0}$ に着目し，次式で表わされる実験式を示している. 


$$
P=\alpha(W / g)\left(V / T_{0}\right)
$$

ここに， $\alpha$ は所定の信頼度を得るための係数である.

この研究では, 実駼結果を用いて, 運動量と力積が近 似的に等しいという理論的な仮定に基づき導出されてい る. しかし, 落石の加速度にその質量を乗じて得られる 衝撃力 (以後, 重鍾衝撃力という) は, さらにサンドクッ ションを介して伝播されることなどを考えると厳密には ロックシェッドに作用する衝撃力を表わしてはいないこ とになる。

吉田・桝谷らは，コンクリート基礎上のサンドクッ ション上への落石実験を行い, 落石の加速度とサンド クッション底面の土压についてその特性を調へ, その結 果, ロックシェッドの荷重を考える場合, 土圧をその作 用範囲で積分して得られる衝撃力 (以後, 積分土圧とい う）の方が落石の加速度よりも合理的なことを明らかに している59) 62).これまで行われた落石実験結果をデー タベース化し，土圧による衝撃力により，式（6）に類 似の形で次のような衝撃力評価式を示している ${ }^{63) ~ 66)}$.

$$
P=\beta_{0}(W / g)\left(V / T_{0}\right)
$$

ここに, $T_{0}$ は衝撃力の作用時間 $(\mathrm{s}), \beta_{0}$ はサンドクッショ ンの厚さの影響を表わす係数で, おのおの次式で表わさ れる.

$$
\begin{aligned}
& T_{0}=(0.0481-0.00064 H) W^{0.270}\left(U_{c} / U_{c 0}\right) \\
& \beta_{0}=-4.81\left(h / h_{0}\right)+5.84 \quad\left(h / h_{0}<1\right) \cdots \\
& \beta_{0}=1.03 \quad\left(h / h_{0} \geqq 1\right) \ldots \ldots \ldots \ldots \ldots \ldots \ldots \ldots . . .
\end{aligned}
$$

ここに, $h$ はサンドクッション厚 $(\mathrm{cm}), U_{c}$ は均等係数, $h_{0}$ は基準サンドクッション厚 $(90 \mathrm{~cm})$ と $U_{c 0}$ は基準均 等係数 $(=1.53)$ である.

\section{（5）衝撃力の分布}

衝撃土圧を測定した最初の研究は文献 58) であり，そ の後の研究においては, 衝撃土圧の測定が一般的となっ ている．衝撃土圧の測定結果より，ロックシェッドに作 用する落石による衝撃力の分布は，落下点下の中央に集 中していることが明らかとなっている.

\section{（6）重鍾衝撃力と積分土圧}

落石実験においては落石をモデル化した重錘が用いら れているが，重鍾がクッション材に衝突したときの重鍾 衝撃力と, 重鍾衝撃力がクッション材中を伝播し, 分散 してクッション材底面に到達したときの積分土圧の比較 は，文献 39）４1），61）でなされており，重錘の底面形 状により異なること，底面が球形の場合は両者がほぼ等 しいこと ${ }^{61)}$ ，クッション材の付加質量の影響が考えられ ること 391 -411などが指摘されている.

\section{（7）ロックシェッドに及ぼす動的影響}

落石による衝撃力がロックシェッドに及ぼす動的影響 を明らかにするために，PC 製ロックシェッド屋根部を 用いて落石実験を行い，ロックシェッドの応答係数の考

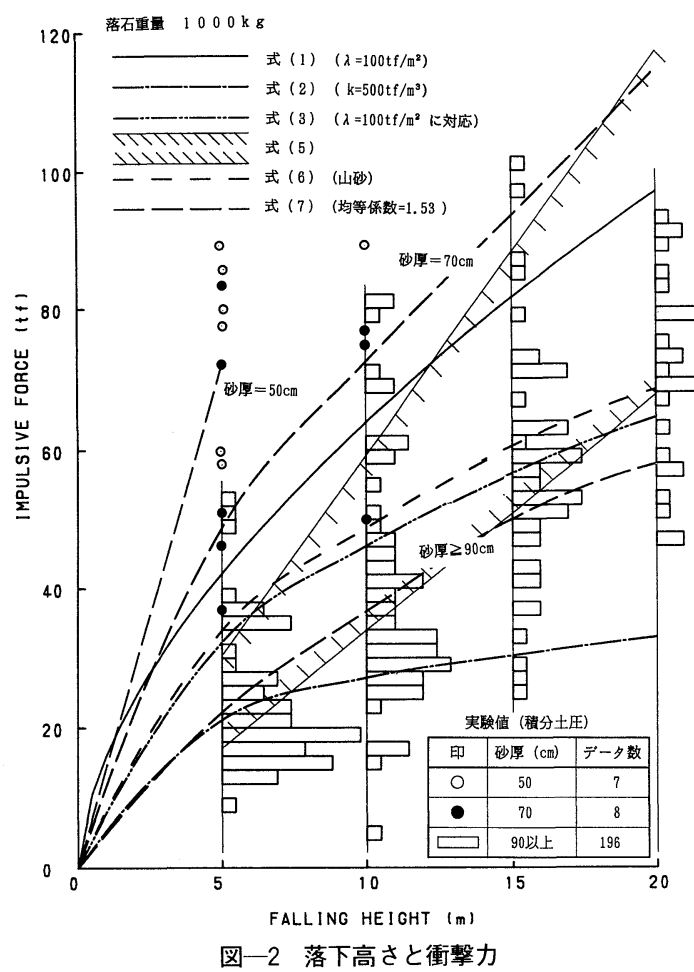

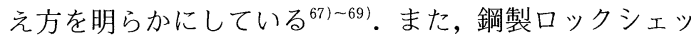
ドに対する理論的検討もなされている70).これは橋梁に おける衝撃係数に対応したものであり，PCロック シェッドにおいては衝撃係数として, 最大 1.4 を取れば よいことを明らかにしている。

\section{（８）衝撃力評価に関するまとめ}

図一2 は重量 $1 \mathrm{t}$ の落石に対する代表的な衝撃力推定 式を示したものである. 参考のために, 吉田, 桝谷ら ${ }^{63) ~-66)}$ が行った実験結果がヒストグラムで示されている. 図中 のヒストグラムは, 各落下高さの縦軸から水平に度数が 取られており，図中の最小ブロックが度数 1 を表わす。

このように，落石の衝撃力評価を目的とした理論的， 実験的な研究が進められ, ある程度は衝撃力の推定が可 能となってきた。しかし，以下のような問題点が残され ている.

a）衝撃力の最大值は, サンドクッションの状態によ り大きな変動が認められる。

b）ロックシェッドの構造特性が及ぼす動的効果を考 慮することが，より合理的と考えられる.

c）ロックシェッドの設計においても, エネルギー吸 収能に基づき設計することが合理的と考えられるが，そ のためには，ロックシェッドの各種の破壊形式，それに 対応する吸収エネルギーについて明らかにする必要があ る.

d）クッション材としてサンドクッション以外のもの 
を用いる場合, 別途, 衝撃力評価についての研究が必要 である ${ }^{36,71 !}$.

\section{5. ロックシェッドの設計}

\section{（1）荷重の種類とそれらの特性}

ロックシェッドには，前述のとおり単に落石のみを防 護するもののほか、なだれとともに落下する小規模の落 石を防護するもの，土砂崩壊および落石を防護するもの などがある。ここでは，簡単のため落石防護のみを対象 としたロックシェッドを取り扱うことにする.

すでに述べたように，現在，ロックシェッドの設計は 落石対策便覧に基づいている．落石対策便覧では，死荷 重, 土圧, 堆積土, 積雪, 落石, 崩土, なだれ, 地震, 自動車衝突，施工時の荷重から，各種の組合せを考え， 設計にあたっては，これらの組合せの中から該当するも のを選択することになっている．ここでは，これらの荷 重のうち，死荷重と落石荷重についてのみ検討する.

\section{a) 死 荷 重}

死荷重は，ロックシェッドを形成している各種構造材 料および付属部材材料に単位体積重量を考慮して求めら れるものと，緩衝材の砂などの重量である.

死荷重の変動は，材料の単位重量の変動および材料の 体積, すなわち，構造物の断面寸法の変動および緩衝材 の厚さの変動に起因しており，後者は前者に比較して多 少大きいとは考えられるが, 他の荷重の変動に比較して きわめて少ない。

b) 落石荷重

ロックシェッドの設計を支配する落石荷重は，すでに 述べたように他の荷重に比較して，その変動はきわめて 大きく，また，設計用の断面力を支配する落石の落下位 置の予測も困難である ${ }^{72)}$.

\section{(2) 合理的設計法}

落石の発生は不規則性の強いものであり，それゆえ落 石の衝撃力は本来確率変量としてとらえるべきものであ る.ロックシェッドの設計には, 落石の重量, 落下高さ, 発生頻度に関する統計資料に基づいた信頼性理論の適用 が理想的亡考えられるが72)，それらの資料が現段階では 不十分であり，信頼性理論の適用は困難である.

また，ロックシェッドの設計法としては，破壞に対す る安全度の確保が弾性理論に基づく許容応力度法より確 実であり，荷重の特性も荷重係数を適当に変えることに より設計に反映することが可能である塑性理論に基づい た終極強度設計法の方が合理的である ${ }^{73)}$ と思われる。

a) 限界状態設計法

ロックシェッドには一般に，鋼製， PC 製および RC 製のものがあるが，ここでは， $\mathrm{PC}$ 製および $\mathrm{RC}$ 製のも のについて述べる．鋼製のものについては，PC 製およ
び RC 製のものと同様の考え方が適用できる。

昭和 61 年に土木学会コンクリート標準示方書 ${ }^{19}$ （以 後，コンクリート示方書という）が大改訂され，限界状 態設計法 ${ }^{721,731}$ が採用された。

コンクリート示方書においては，限界状態として，終 極限界状態，使用限界状態および疲労限界状態に区分し ているが，ロックシェッドにおいては，疲労限界状態に ついては検討する必要がなく，終極限界状態および使用 限界状態の 2 つついて検討する。

前述のとおり，荷重には変動があるので，設計におい て考慮する荷重として，コンクリート示方書では，荷重 の特性値を用いることを想定している，さらに，終極限 界状態の検討に用いる荷重の特性値は,「荷重のばらつ きを考慮したうえで，構造物の施工中および耐用期間中 に生ずる最大または最小荷重の期待值」とし，使用限界 状態の検討に用いる荷重の特性值は，「構造物の耐用期 間中に，比較的しばしば生ずる大きさのもの」と定義さ れている.

限界状態設計法では，これらの特性值を用いて計算さ れた設計用の断面力 $S_{d}$ と試験值の変動を想定したうえ で，大部分の試験值がその值を下回らないように設定さ れた材料強度の特性值 $f_{k}$ を用いて計算された断面の耐 力などの抵抗值 $R_{d}$ が次式を満足すれば，構造物の安全 性が保証される。

$$
R_{d} / S_{d} \geqq \gamma_{i}
$$

ここに, $\gamma_{i}$ は構造物の重要度, あるいは, 限界状態に 達したときの社会的影響の程度を考慮するための構造物 係数である.

b）ロックシェッドの限界状態

コンクリート示方書には，使用限界状態および終極限 界状態に対するいくつかの例が挙げられている. ロック シェッドの使用限界状態および終極限界状態について検 討してみる。

使用限界状態——ここで検討しているロックシェッド の使用限界状態には 2 通りの状態が考えられる.第 1 は, ひびわれの使用限界状態で，ひびわれにより美観を害す るか, 耐久性または水密性を損ねる状態であり, 第 2 は, 損傷の使用限界状態で，ロックシェッドに各種の原因に よる損傷が生じ，そのまま使用するのが不適当となる状 態が考えられる，これに対する荷重としては，生起確率 が大きい落石（比較的頻繁に発生する落石）に対するも のである.

終極限界状態——ロックシェッドの終極限界状態とし ては，部材の断面が破壊に至る場合に相当する．ただし， 部材の断面の破壞により, コンクリートの破片が落下し， 通行車両などに被害が生じない範囲の破壊と考えねばな らない。この程度の断面の破壊においては，車両限界を 
越えるような大きな変位, 変形は生じない.もちろん, 剛体としての安定性は保たれているものとする. 不静定 構造物の場合に，メカニズムへ移行するほどの大きな部 材断面の変形は, コンクリートの破片の落下などの可能 性があり, ロックシェッドの終極限界状態としては好ま しくない.

終極限界状態に対する荷重としては，ロックシェッド の耐用期間中に考えられる最大の落石（現時点では落下 することはないが, 将来, 落下の可能性がある岩石）荷 重，または，堆積土荷重と落石荷重または地震荷重の組 合せ，およびそれらすべての組合せなどが考えられる.

c）荷重の組合せと安全係数

ロックシェッドの設計に際し落石対策便覧では, いく つかの荷重の組合せを提唱している。このうち，たとえ ば落石と堆積土は同時に作用させないこと，地震時の検 討においては, 堆積土を $100 \%$ 考慮することになって いることなど, 実際の設計にマッチしない例もみられる.

このような矛盾は, 現行設計法では, 限界状態設計法 における荷重係数および荷重の組合せ係数をすべて 1.0 にとっており, 許容応力度の割増のみで同時に作用する 荷重の不確実性をカバーしようとしていることに起因し ている.

すでに述べたとおり, 落石荷重を生起確率が大きい落 石に対するものと，ロックシェッドの耐用期間中に落下 の可能性がある比較的大きい落石, すなわち, 生起確率

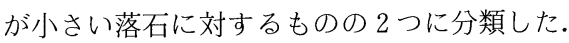

それらのおのおのに対し，ロックシェッドの限界状態 設計における材料係数, 部材係数, 構造物解析係数およ び構造物係数は，コンクリート示方書に示される標準的 な安全係数を採用してよいと考えられるが, 荷重組合せ 係数は, 同時に作用する荷重の生起確率などを考慮して 定める必要がある.

荷重係数は，4.で述べた荷重の変動, 荷重の算出方 法の不確実性, 荷重特性が限界状態に及ぼす影響などを 考慮して決定する必要がある.

限界状態確率に基づく荷重の組合せ係数および荷重係 数の決定法としていくつかの方法が提案されているが, 現行の設計に整合させながら, 均一な信頼性を確保する ような荷重係数の組合せを算定するキャリブレーション 法 $^{74)}{ }^{75)}$ などが考えられる.

d）ロックシェッドの設計

これまでの検討より, 以下に示す手法によるロック シェッドの設計法が望ましいと考えられる．2. に述べ た手順に従って説明する.

調査一一斜面に存在する岩塊のうち, 落下する可能性 の大きいものについて重量, 形状, 位置などを調査する. また，すぐには落下しないが，将来，落下が予想される
岩塊についても，同様の調査を行う.

シミュレーション一比較的頻繁に落下が予想される 岩塊および将来落下が考えられる大きな岩塊について, 落下のシミュレーションを行い, ロックシェッドに到達 するときの速度および位置の分布を求める．落石の速度 より求める推定衝撃力の不確実性および落下速度の不確 実性より荷重の特性值 $f_{k}$ および荷重係数 $\gamma_{f}$ を設定す る. また, 落下位置の推定の不確実性を考慮して, 構造 解析係数 $\gamma_{a}$ を設定する.

終極限界状態の検討一一荷重の生起確率に応じて許容 し得る損傷限度を設定する。たとえば，生起確率の比較 的大きい荷重に対しては，ほとんど補修を必要としない 軽微な損傷程度のわずかなひびわれまでを, 生起確率の きわめて小さい荷重に対しては, 崩壊（人命の損失の可 能性がある) は避けるが，ひびわれが顕著で剝落が発生 するような再使用不能の損傷は許容するなどの検討が必 要である.

構造上の検討一—せん断による脆性的な破壊を避ける ため, せん断に対する安全度を曲げに対する安全度より 大きくとる，また，急激な破壊を防ぐために，構造上の 塑性ヒンジが形成される部分には十分な靶性をもたせる などの配慮が必要である ${ }^{76)}$.

さらに, 構造物が塑性変形性能を発揮し, 損傷が想定 した損傷以内に収まるように，たとえば，シアスパン比 を大きくとる, 軸方向鉄筋比を小さくする, 軸方向圧縮 応力比を小さくする，スターラップ比，带鉄筋比を大き くするなどの構造細目について, 十分な検討が必要であ $る^{76)}$.

\section{6. あとがき}

本報告では, 落石防護工の設置にあたっての, 斜面調 査, これに基づく落石防護工, 特に, ロックシェッドの 設計の現状と問題点を概説するとともに, これらに関連 する研究成果と今後の展望について解説した. さらに, より合理的な設計の考え方の提案も行った.

今後の落石防護工の設計に参考になるところがあれば 幸いである.

\section{参 考 文 献}

1) Heierli, W., Merk, A. and Temperli, A. : Schutz gegen Steinschlag (2. Auflage), Eidgenossisches Verkehrs und Energiewirtschaftsdepartment Bundesamt fur Strassenbau, pp. 21 29, Nov., 1985.

2）日本鉄道施設協会 : 落石対策の手引, pp. $78 \sim 148,1978$ 年 3 月.

3） 日本道路協会：落石対策便覧，pp. 1 239，1983 年 7 月.

4）建設省道路局：一般国道 305 号崩落事故の概要, 道路, No. 582, pp. $64 \sim 65,1989$ 年 8 月. 
5）平野昌繁・奥西一夫・諏訪 浩：1989 年越前海岸落石災 害に見られる地形地質特性之岩盤崩壞過程, 第 8 回日本 自然災害学会学術講演会要旨集, pp. 60 61, 1989 年 9 月.

6）池田和彦・小橋澄治：地形・地質からみた落石の傾向之 発生予測，施工技術，Vol.6, No. 8, pp. 17 21, 1973 年 8 月。

7）馬場和秋 - 吉川利雄：落石の予知, 施工技術, Vol. 6, No. 8, pp. 23〜31, 1973 年 8 月.

8）馬場亮介・高木 寿：国鉄における落石の実態と対策一 四国の場合一，施工技術，Vol.6, No.8, pp. 32 39, 1973 年 8 月.

9）中村直衛 - 村上敏雄 - 大山保束 : 落石予知亡対策工一愛 岐道路の例一, 施工技術, Vol. 6, No.8, pp.40 47, 1973 年 8 月.

10）清家幸蔵：落石予知亡対策工一静岡県の場合一, 施工技 術, Vol. 6, No. 8, pp. 48 51, 1973 年 8 月.

11）森野亮宏：斜面の災害危険度と崩壊発生の予測に関する 研究，鉄道技術研究所，1985 年 3 月.

12）高速道路調查会：落石防護施設の設置に関する調查研究 報告書, 1974 年 2 月.

13）道路防災施設調査特別委員会：道路防災施設調查報告書, 1980 年 3 月.

14）箭内寛治：落石の調查と対策，地質と調査，No. 33, pp. 38 46, 1987 年.

15）村上幸利・箭内寛治：転落型落石の発生機構に関する基 礎的研究, 土質工学会論文報告集, Vol. 27, No. 1, pp. 109 116, 1987.

16）村上幸利・箭内寛治：転落型落石の危険度評価法につい て, 土質工学会論文報告集, Vol. 28, No. 3, pp. 197 203, 1988 年 9 月.

17) 建設省土木研究所：落石防災対策に関する調査報告書 (そ の 1), (その2), 土木研究所資料, No.2770, 2771, 1989 年 2 月.

18）日本道路協会：道路橋示方書 - 同解説，日本道路協会， 1978 年.

19）土木学会：コンクリート標準示方書・設計編，土木学会, 1986 年 10 月.

20）檜貝 勇：コンクリート標準示方書を道路橋などの設計 に適用する場合の問題点, コンクリート工学, Vol.27, No. 9, 1989 年 9 月.

21）右城 猛・大原健史・明坂宣行・吉崎和人：実験デー夕 を用いた落石の運動軌跡のシミュレーション, 第 2 回落 石の衝撃力およびロックシェッドの設計に関するシンポ ジウム論文集, pp. 88〜 91, 1986 年 7 月.

22）佐々木康・谷口栄一・舟見清巳 - 谷本 旦 - 堀口正巳 : 落石の跳躍量に関する実験, 第 14 回日本道路会議特定課 題論文集, pp. 113 115，1981 年 10 月.

23）右城 猛・村上哲彦：落石の飛跳高の推定, 第 1 回落石 の衝撃力およびロックシェッドの設計に関するシンポジ ウム論文集, pp. $48 \sim 54,1983$ 年 7 月.

24）日本道路公団東京支社, 建設企画コンサルタント：落石 実験調査報告書, 1973 年 11 月.

25）日本道路公団東京支社, 建設企画コンサルタント：愛岐 落石防護柵耐衝撃力測定実験報告書, 1973 年 11 月.

26）神戸大学工学部土木工学科・(株) 神戸製鋼所：神鋼型落
石防止柵実地試験報告書, 1967 年 4 月.

27）吉田 博 - 右城 猛・柴田健治・栘谷 浩：斜面上の落 石の運動形態に関する研究, 落石防災研究会, 1989 年 8 月.

28）古賀泰之・伊藤良弘・鷲田修三・森下 義：落石の運動 軌跡の予測法に関する検討, 土木技術資料, Vol. 31, No. 8, 1989 年 8 月.

29）福岡正巳 : 落石の運動機構について, 第 11 回日本道路会 議特定課題論文集, pp. 96 98, 1973 年 10 月.

30）右城 猛: $2 \cdot 3$ の落石斜面でのシミュレーション解析の 検証, 北陸道路研究会 35 周年記念シンポジウム論文集, 1988 年 10 月.

31）建設省土木研究所・(株) 建設企画コンサルタント：落石 の跳躍量に関する現場実験報告書，1980 年 10 月.

32）福岡正巳：落石の機構, 施工技術, Vol. 6, No. 8, pp. 14 $\sim 16,1973$ 年 8 月.

33）大房高明・福田富男：落石による擁壁の衝突速度と落下 軌跡の算定, 土木技術, Vol. 33 , No. 5, pp. $36 \sim 41$, 1978 年 5 月.

34) Rochet, L. : Application des modeles numeriques de propagation a 1'etude des eboulements rocheux, Bulletin de liaison des laboratoires des ponts et chaussees, No. 150-151, pp. 84 95, Sept. -Oct., 1987.

35）斎藤武文・吉田 博・栘谷 浩: 落石の落下位置および 速度に関する一推定法, 第 2 回落石の衝撃力およびロッ クシェッドの設計に関するシンポジウム論文集, pp. 98 〜104, 1986 年 7 月.

36）吉田 博：ヨーロッパにおけるなだれ・落石防護工につ いて, 北陸道路研究会 35 周年記念シンポジウム論文集, pp. 1 14, 1988 年 10 月.

37) Ritchie, A.M. : An Evaluation of Rockfall and it's Control, Research Project No. HPS1-(22), Department of Highways, Washington State Highway Commission, April, 1963.

38）土木学会：土木技術者のための振動便覧，pp. 320～324, 1985 年 10 月.

39）建設省土木研究所動土質研究室 : 敷砂上の落石の衝撃力 に関する実験報告書，土木研究所資料，第 1822 号，1982 年 3 月.

40）佐々木康・古賀泰之：敷砂上の落石の衝撃力に関する実 験的研究, 土木学会論文報告集, No. 340, pp. 127 137, 1983 年 12 月.

41）古賀泰之・佐々木康：敷砂上の落石の衝突現象に関する 考察, 土木学会論文集, No. 346, pp. 27〜35, 1984 年 6 月.

42）和仁達美・赤沢 稔：鉄道土木施工法, 山海堂, pp. 263 $\sim 271,1963$ 年 4 月.

43）園田恵一郎・小林治俊・鈴木輝男：ロックシェッドに対 する落石荷重計算法 (ヘルツ式の改良) について，第 1 回落石の衝撃力およびロックシェッドの設計に関するシ ンポジウム論文集, pp. 25〜35, 1983 年 7 月.

44）三上敬司・能町純雄・松岡健一：落石覆工への落石によ る衝撃力に関する評価, 第 2 回落石の衝撃力およびロッ クシェッドの設計に関するシンポジウム論文集別冊, pp. 1 10, 1986 年 7 月. 
45）三上敬司・能町純雄・松岡健一・岸 徳光: 落石による 落石覆工への衝撃力に関する評価, 構造工学論文集, Vol. 33 A, pp. 559 569, 1987 年 3 月.

46）岸 徳光・吉田紘一・松岡健一・能町純雄 : 層状弾性体 にモデル化した覆工敷砂部の衝撃応答解析, 構造工学論 文集, Vol. 34 A, pp. 817 826, 1988 年 3 月.

47）吉田 博・桝谷 浩・今井和昭：個別要素法による敷砂 上への落石の衝撃特性に関する解析, 土木学会論文集, No. 392, pp. 297 306, 1988 年 4 月.

48) Cundall, P.A., Strack, O. D. L. : A Discrete Numerical Model for Granular Assemblies, Geotechnique, Vol.29, No. 1, pp. 47 65, Jan., 1979.

49) 木山英郎・藤村 尚：カンドルの離散剛要素法を用いた 岩質粒状体の重力流動の解析, 土木学会論文報告集, No. 333, pp. $137 \sim 146,1983$ 年 5 月.

50) 大町達夫・荒井靖博 : 個別要素法で用いる要素定数の決 め方について, 構造工学論文集, Vol. 32 A, pp. 715 723, 1986 年 3 月.

51）園田恵一郎：限界状態設計法とロックシェッドの設計, 北陸道路研究会 35 周年記念シンポジウム論文集, pp. 22 - 34, 1988 年 10 月.

52）齋藤英明・石川信隆・大野友則・水山高久：鋼管片持ば りの衝撃吸収エネルギーに関する基礎的研究，土木学会 論文集，No. 386／I-8，pp. 321 328，1987 年10月.

53）矢澤昭夫・水山高久・下東久巳：土石流中の巨碩の衝突 による鋼管の変形, 第 2 回落石の衝撃力およびロック シェッドの設計に関するシンポジウム論文集, pp. 54 57,1986 年 7 月.

54）鋼製砂防構造物委員会：鋼製砂防構造物設計便覧, 砂防・ 地すべり技術センター, 1987 年.

55）吉田 博・石塚賢吉・細川 豊：落石によるロック・ シェード上の落石による衝撃力の推定法に関する研究, 道路, No. 444, pp. $38 \sim 43,1978$ 年 2 月.

56）吉田 博 - 桝谷 浩: 落石の衝撃力実験結果と各種推定 式の関連について, 第 1 回落石の衝撃力およびロック シェッドの設計に関するシンポジウム論文集，pp. 9 16, 1983 年 7 月.

57）鋼材俱楽部：新しい落石覆いの開発に関する研究, 研究 報告書, 1973 年 4 月.

58）吉田 博 - 竹島 忠・古市進作・石塚賢吉：ロック・ シェード上の落石による衝撃力の推定に関する実験, 道 路, No. 428, pp. $35 \sim 41,1976$ 年 10 月.

59）吉田 博 - 桝谷 浩 - 鈴木哲次 - 岡 衛 - 永木卓美： サンドクッション上への落石の衝撃力とその伝播につい て, 第 1 回落石の衝撃力およびロックシェッドの設計に 関するシンポジウム論文集, pp. 1 8, 1983 年 7 月.

60）金沢大学工学部構造力学研究室：防護覆い上への落石に よる衝撃力の推定に関する研究, 落石実験報告書 ( I ), 1984 年 1 月.

61）吉田 博 - 桝谷 浩-鈴木哲次: 敷砂上の落石の衝撃加 速度之衝撃土圧に関する実験的研究，土木学会論文集，
No. 352, pp. 61 70, 1984 年 12 月.

62) Yoshida, H., Masuya, H. and Ihara, T. : Experimental Study of Impulsive Design Load for Rock Sheds, IABSE Proceedings P-127/88, pp. 61 74, Aug., 1988.

63）吉田 博 - 桝谷 浩 - 佐藤 真・井原朋美：落石実験 データベースの作成と落石の衝撃力評価について, 構造 工学論文集, Vol. 33 A, pp. $571 \sim 583,1987$ 年 3 月.

64）桝谷 浩・佐藤 真・吉田 博：落石実験データベース の作成について, 第 2 回落石の衝撃力およびロックシェッ ドの設計に関するシンポジウム論文集, pp. 58 63, 1986 年 7 月.

65）柝谷 浩・吉田 博・佐藤 真：落石実験データベース に基づく衝撃力の評価, 第 2 回落石の衝撃力およびロッ クシェッドの設計に関するシンポジウム論文集, pp. 64 $\sim 70,1986$ 年 7 月.

66）吉田 博・杪谷 浩：落石覆の設計荷重の評価に関する 研究, 昭和 $58 \sim 59$ 年度文部省科学研究費補助金 (試験研 究 $(2))$, 研究成果報告書, 1985 年 3 月.

67）吉田 博・細川 豊・石塚賢吉：落石によるロック・ シェードの動的効果に関する実験, 道路, No.438, pp. $54 \sim 58,1977$ 年 8 月.

68）吉田 博 - 桝谷 浩・岡 衛: 落石覆工屋根上への落 石による衝撃荷重特性について, 土木学会論文集, No. 362, pp. $461 \sim 470,1985$ 年 10 月.

69）金沢大学工学部構造力学研究室, ピー・エス・コンクリー ト：実物落石覆工の落石実験について, 実験報告書, 1979 年 12 月.

70）合津 尚・岩村二三男・橘 吉宏：固有周期を考慮した 鋼製ロックシェッドの構造に関する考察，第 2 回落石の 衝撃力およびロックシェッドの設計に関するシンポジウ ム論文集, pp. 132 139，1986 年 7 月.

71）佐野常昭・松井 清- 吉田 博 - 桝谷 浩 - 清水 公: 鋼製防護壁上への落石実験について, 第 2 回落石の衝撃 カおよびロックシェッドの設計に関するシンポジウム論 文集, pp. 9 20, 1986 年 7 月.

72）園田恵一郎・小林治俊・鈴木輝男：信頼性設計法のロッ クシェッドへの適用の一試み, 第 2 回落石の衝撃力およ びロックシェッドの設計に関するシンポジウム論文集, pp. 110 117, 1986 年 7 月.

73）岡村 甫：コンクリート構造の限界状態設計法, 第 2 版, 共立出版, 1979 年 6 月.

74) Sinozuka, M. : Load Combination and Load Resistance Factor Design, Proc. of IABSE Symposium, Tokyo, Sept., 1986.

75）篠塚正宣・久保雅邦：限界状態確率に基づく設計荷重の 組合せと荷重係数の一決定法，土木学会論文集，No. 386 ／ I -8, pp. $301 \sim 310 ， 1987$ 年 10 月.

76）太田 実：ロックシェッド設計に対する基本的考え方に ついて, 第 2 回落石の衝撃力およびロックシェッドの設 計に関するシンポジウム論文集，別冊，1986 年 7 月.

(1990.2.9 • 受付） 